\title{
VARIATION OF SPRING BARLEY AGRONOMIC TRAITS SIGNIFICANT FOR ADAPTION TO CLIMATE CHANGE IN LATVIAN BREEDING PROGRAMMES
}

\author{
*Māra Bleidere, **leva Mežaka, **Linda Legzdiṇa, *Ilze Grunte, **Indra Beinaroviča, \\ and ${ }^{* * *}$ Nils Rostoks \\ * State Stende Cereal Breeding Institute, "Dižzemes", Dižstende, Lïbagu pag., Talsu nov., LV-3258, LATVIA \\ maara.bleidere@stendeselekcija.Iv \\ ** State Priekuḷi Plant Breeding Institute, Priekuḷi, LV-4126, LATVIA \\ lindaleg@ navigator.Iv \\ *** Faculty of Biology, University of Latvia, 4 Kronvalda bulv., Rīga, LV-1586, LATVIA \\ nils.rostoks@lu.lv
}

Contributed by Zinta Gaile

\begin{abstract}
Breeding programmes have been recently challenged by climate change. Spring barley (Hordeum vulgare L.) yield, phenological traits (days to heading, length of filling period and days to maturity) and resistance to powdery mildew and net blotch, which are influenced by the rising temperature and precipitation, along with threshability in hulless, were evaluated and their genetic and environmental variability were determined. One hundred and ninety spring barley genotypes were studied, including 129 hulless genotypes and 61 hulled genotypes. The genotypes were grown in the State Stende Cereal Breeding Institute and State Priekuli Plant Breeding Institute for three seasons during 2007-2009. Broad-sense heritability estimated on the basis of genotypical and phenotypical variances for all traits of hulled barley varied from 31 to 98, and 42 to $98 \%$ for hulless barley. For both types of barley the highest heritability was observed for days to heading, filling period and days to maturity. Despite the relatively high estimated heritability for all traits, nevertheless, location, year and interaction of genotype and environment were also been significant for all traits.
\end{abstract}

Key words: spring barley, hulled and hulless, agronomic traits, variation, heritability.

\section{INTRODUCTION}

Barley (Hordeum vulgare L.) is one of the main crops in many areas of the world, including Latvia. Hulled barley breeding in Latvia was started at 1924, and in 2000 hulless barley breeding was initiated (Legzdina and Mezaka, 2010). The main objectives of the Latvian spring barley breeding programmes at the State Stende Cereal Breeding Institute and State Priekuli Plant Breeding Institute are to develop varieties of covered and hulless spring barley with improved yield and nutritional quality adapted to changing agrometeorological conditions. Modelled climate changes include increased precipitation (Dai, 2011) and increased mean annual surface air temperature (Olesen et al., 2011). Therefore, high yielding barley with good resistance to lodging and resistance to leaf diseases with phenology conforming to ecological conditions is demanded. Alongside the traits mentioned for hulled barley, hulless barley additionally has to be evaluated for threshability, as hulless barley grain with undetached hulls loses its superiority over covered barley (Rossnagel, 2000).
Selection of germplasm or working collections with useful genetic variation to achieve higher variation of yield and other desirable agronomic traits is a crucial activity for any plant breeder. It is important to know the magnitude of the interactions in the selection of genotypes across several environments, besides calculating the average performance of the genotypes being evaluated (Gauch and Zobel, 1997). A proper understanding of the environmental and genetic factors causing the interaction as well as an assessment of their importance in the relevant G X E system could have a large impact on plant breeding (Basford and Cooper, 1998). Heritability is a parameter widely used in the establishment of breeding programmes and calculation of selection indexes. In general, heritability of traits of agronomical importance is low due of their polygenic nature (Novoselovic et al., 2004). However, genetic variation and heritability estimates are unique to a particular breeding material and these genetic properties are dependent on variation due to environment and genetic background of genotypes.

The present study was undertaken to evaluate the range of variation in some agronomic traits of spring barley geno- 
types in the growing conditions of Latvia. The aim of this study was to determine the variation of agronomic traits and their heritability in covered and hulless spring barley genotypes included in Latvian breeding programmes.

\section{MATERIALS AND METHODS}

One hundred and ninety spring barley genotypes were studied, including 129 hulless genotypes and 61 hulled genotypes. Most of the genotypes are Latvian varieties and breeding lines (88-hulled, 43-hulless). Genotypes with contrasting scores for resistance to sprouting in ears, fusarium head blight (Fusarium spp.) and powdery mildew (Blumeria graminis L. f.sp. hordei), content of lysine and beta-glucans as well as genotypes with several loose smut (Ustilago nuda (Jens.) Rostr.) resistance genes and low phytate mutants were chosen for the study. A further aim was to use phenotyping data for association mapping and to choose parents for breeding and creation of RIL populations. Genotypes were grown in the State Stende Cereal Breeding Institute (Stende) and State Priekul,i Plant Breeding Institute (Priekulii) for three seasons during 2007-2009. The field trials at each location were arranged by a randomised complete block design grown in three replicates in $2 \mathrm{~m}^{2}$ field plots.

The soil at the Stende site was sod-podzolic sandy loam, the humus content was $12-16 \mathrm{~g} \mathrm{~kg}^{-1}$, the soil $\mathrm{pH} \mathrm{KCl} \mathrm{-}$ 5.9-6.3, available phosphorus $\mathrm{P}_{2} \mathrm{O}_{5}-182-334 \mathrm{mg} \mathrm{kg}^{-1}$, and potassium $\mathrm{K}_{2} \mathrm{O}-137-250 \mathrm{mg} \mathrm{kg}^{-1}$. The pre-crop was potatoes. Before cultivation of the soil a complex mineral fertilizer was applied: $\mathrm{N}-80, \mathrm{P}_{2} \mathrm{O}_{5}-47, \mathrm{~K}_{2} \mathrm{O}-66, \mathrm{~S}-56 \mathrm{~kg} \mathrm{ha}^{-1}$. The soils at the Priekuli site were sod-podzolic sandy-loam (2008) and gley-podzolic sandy-loam soil (2007 and 2009) with humus content $21-27 \mathrm{~g} \mathrm{~kg}^{-1}$, the soil $\mathrm{pH} \mathrm{KCl} \mathrm{5.2-6.4,}$ available phosphorus $\mathrm{P}_{2} \mathrm{O}_{5}$ a $122-400 \mathrm{mg} \mathrm{kg}^{-1}$, and potassium $\mathrm{K}_{2} \mathrm{O}$ 76-153 $\mathrm{mg} \mathrm{kg}^{-1}$. The pre-crop was potatoes. Before cultivation of the soil a complex mineral fertilizer was applied: $\mathrm{N}-80-81, \mathrm{P}_{2} \mathrm{O}_{5}-40-53, \mathrm{~K}_{2} \mathrm{O}-67-105 \mathrm{~kg}$ $\mathrm{ha}^{-1}$. Herbicides and insecticides were used for weed and insect control in both sites.

Meteorological conditions in the years and locations of the investigation varied significantly. The precipitation sum in May 2007 was significantly lower $(42.3 \mathrm{~mm})$ in the Stende location compared with Priekuli $(78.6 \mathrm{~mm})$. In May and in June the average temperature was higher than the long-term average and with moisture was sufficient in both locations. July was cool and wet in both study locations. August of 2007 was wet with mean temperature $2{ }^{\circ} \mathrm{C}$ higher than the long-term average in both locations. In 2008, in Priekuli the amount of rainfall was insufficient in the first part of the vegetation period (from May to July), and it was very rainy in August in the period close to the maturity stage. In Stende only May was warm and characterized with insufficient amount of rainfall, but the period from June to August was cool and very moist. In 2009, the mean air temperature and moisture conditions were rather similar in both loca- tions. In April and May, there was a precipitation deficit, while the average monthly air temperature in April and May were higher than the long-term average. June was the first month with average air temperature below normal, but with heavy rain in both locations. July of 2009 was hot and wet in both study locations.

For both types of barley, agronomic traits such as grain yield $\left(\mathrm{t} \mathrm{ha}^{-1}\right)$, lodging resistance $(1-$ totally lodged; 9 fully upright), infection with powdery mildew (PM) and net blotch (NB) (Drechlera teres L.) ( 0 - no infection; 4 - very high infection) were examined. For hulless barley threshability (THR) was determined ( 0 - no hulls; 4 - all grains with undetached hulls). To estimate "days to heading" (DTH) and "days to maturity" (DTM), the number of days between sowing and the time at which $50 \%$ of the ears had emerged/matured was counted (growing stages 55 and 92, respectively). The grain-filling period (GFP) was estimated as the difference in days between those needed to reach maturity and days from sowing to heading.

Analysis of variance was carried out using Microsoft Excel ("Microsoft", USA). Results of ANOVA were combined over locations and years to calculate the components of variance explained by replications $(\mathrm{r}=3)$, year $(\mathrm{y}=3)$ and locations $(\mathrm{l}=2)$ and the broad-sense heritability $\left(\mathrm{H}^{2}, \%\right)$ (Gordon et al., 1972) (Table 1):

$\mathrm{H}^{2}=\delta_{\mathrm{G}}^{2} / \delta_{\mathrm{P}}^{2}=\delta_{\mathrm{G}_{\mathrm{G}}}^{2} /\left(\delta_{\mathrm{R}}^{2}+\delta_{\mathrm{L}}^{2}+\delta_{\mathrm{Y}}^{2}+\delta_{\mathrm{LY}}^{2}+\delta_{\mathrm{G}}^{2}+\delta_{\mathrm{GY}}^{2}+\right.$ $\left.\delta^{2}{ }_{\mathrm{GL}}+\delta_{\mathrm{GLY}}^{2}+\delta_{\mathrm{E}}^{2}\right)$

where, $\delta^{2}{ }_{\mathrm{G}}$ is the genotypical variance, $\delta_{\mathrm{P}}^{2}$ is the phenotypical variance, $\delta_{\mathrm{R}}^{2}$ is the variance among replications, $\delta_{\mathrm{L}}^{2}$ is the variance of the locations, $\delta_{Y}^{2}$ is the variance of the years, $\delta_{\mathrm{LY}}^{2}$ is the location $*$ year interaction variance, $\delta_{\mathrm{GY}}^{2}$ is the genotype * year interaction variance, $\delta^{2}{ }_{\mathrm{GL}}$ is the genotype $*$ location variance, $\delta^{2}{ }_{\mathrm{GLY}}$ is the genotype * location $\mathrm{x}$ year interaction variance and $\delta_{\mathrm{E}}{ }^{2}$ is the error variance.

In the analysis of variance, the partitioning of sum of squares $\left(\eta^{2}\right)$ due to the relative impact of each single factor was estimated. The significance of effect of factors was determined at probability levels of 0.05 and 0.01 . Differences between means were calculated by t-test.

Table 1

ESTIMATION OF VARIANCE COMPONENTS OF ANOVA

\begin{tabular}{l|cll}
\hline Source of variation & Mean square & \multicolumn{1}{c}{ Variance component } \\
\hline $\mathrm{G}$ & $\mathrm{M}_{1}$ & $\delta_{\mathrm{G}}^{2}=\left(\mathrm{M}_{1}-\mathrm{M}_{4}-\mathrm{M}_{5}-\mathrm{M}_{7}\right) / \mathrm{ryl}$ \\
$\mathrm{L}$ & $\mathrm{M}_{2}$ & - \\
$\mathrm{Y}$ & $\mathrm{M}_{3}$ & - \\
$\mathrm{G} \times \mathrm{L}$ & $\mathrm{M}_{4}$ & $\delta_{\mathrm{GL}}^{2}=\left(\mathrm{M}_{4}-\mathrm{M}_{7}\right) / \mathrm{ry}$ \\
$\mathrm{G} \times \mathrm{Y}$ & $\mathrm{M}_{5}$ & $\delta_{\mathrm{GY}}^{2}=\left(\mathrm{M}_{5}-\mathrm{M}_{7}\right) / \mathrm{rl}$ \\
$\mathrm{L} \times \mathrm{Y}$ & $\mathrm{M}_{6}$ & - \\
$\mathrm{G} \times \mathrm{L} \times \mathrm{Y}$ & $\mathrm{M}_{7}$ & $\delta_{\mathrm{GLY}}^{2}=\left(\mathrm{M}_{7}-\mathrm{M}_{8}\right) / \mathrm{r}$ \\
Pooled error & $\mathrm{M}_{8}$ & $\delta_{\mathrm{E}}^{2}=\mathrm{M}_{8}$
\end{tabular}




\section{RESULTS}

Grain yield. ANOVA showed that the grain yield for hulled and hulless barley in the tested varieties was significantly $(P<0.01)$ influenced by all three main factors (genotype, year, location) and their interaction (Tables 2, 3). For both types of barley the variation in yield was mainly determined by genotype $\left(\eta_{\text {hulled }}^{2}=26 \%, \eta_{\text {hulless }}^{2}=27 \%\right)$ and year $\left(\eta^{2}\right.$ hulled $\left.=34 \%, \eta_{\text {hulless }}^{2}=27 \%\right)$ and to a lesser extent by location and interaction of factors. Significantly higher mean annual grain yield was obtained in the Stende location: between 1.8 and $6.2 \mathrm{t} \mathrm{ha}^{-1}$ (average $4.6 \mathrm{t} \mathrm{ha}^{-1}$ ) for hulled barley and between 2.1 and $5.1 \mathrm{t} \mathrm{ha}^{-1}$ (average $3.6 \mathrm{t}$ $\mathrm{ha}^{-1}$ ) for hulless barley. The variation in grain yield among the genotypes was wider in Stende than in Priekuli location (Table 4). A significantly higher mean grain yield was observed in 2009 (Table 5) for both types of barley.

Days to heading. For hulled and hulless barley the variation in days to heading was significantly $(P<0.01)$ influenced by all factors and their interaction. For both types of barley the effect of the year (growing season) explained by variance in days to heading was relatively small $\left(\eta^{2}\right.$ hulled $=$ $7 \%, \eta_{\text {hulless }}^{2}=8 \%$ ) in comparison to the genotype effect $\left(\eta^{2}\right.$ hulled $\left.=61 \%, \eta_{\text {hulless }}^{2}=52 \%\right)$. Interaction of year and location had a rather high influence $\eta_{\text {hulled }}^{2}=16 \%, \eta_{\text {hulless }}^{2}=$ $21 \%)$. The length of growing period from sowing to heading for hulled barley genotypes was 57 and 55 days in

Table 2

PARTITIONING OF SUM OF SQUARES $\left(\eta^{2}\right)$ FOR HULLED BARLEY AGRONOMIC TRAITS PRIEKULI, STENDE, 2007-2009

\begin{tabular}{l|c|c|c|c|c|c|c|c}
\hline \multicolumn{1}{c}{ Source } & df & GY & DTH & GFP & DTM & LOD & PM & NB \\
\hline Genotype (G) & 128 & $26^{* *}$ & $61^{* *}$ & $25^{* *}$ & $29^{* *}$ & $18^{* *}$ & $34^{* *}$ & $13^{* *}$ \\
Year (Y) & 2 & $34^{* *}$ & $7^{* *}$ & $36^{* *}$ & $42^{* *}$ & $12^{* *}$ & $4^{* *}$ & $37 * *$ \\
Location (L) & 1 & $1^{* *}$ & $6^{* *}$ & $1^{*}$ & $1^{*}$ & $27^{* *}$ & $41^{* *}$ & $1^{* *}$ \\
G x Y & 256 & $9^{* *}$ & $2^{* *}$ & $4^{* *}$ & $4^{* *}$ & $8^{* *}$ & $6^{* *}$ & $10^{* *}$ \\
Y x L & 2 & $2^{* *}$ & $16^{* *}$ & $23^{* *}$ & $15^{* *}$ & $16^{* *}$ & $0.2^{*}$ & $6^{* *}$ \\
G x L & 128 & $5^{* *}$ & $2^{* *}$ & $3^{* *}$ & $3^{* *}$ & $5^{* *}$ & $5^{* *}$ & $8^{* *}$ \\
G x Y x L & 256 & $6^{* *}$ & $5^{* *}$ & $8^{* *}$ & $7^{* *}$ & $6^{* *}$ & $4^{* *}$ & $6^{* *}$
\end{tabular}

GY, grain yield, DTH, days to heading, GFP, grain filling period, DTM, days to maturity, LOD, lodging resistance, $\mathrm{PM}$, powdery mildew, NB, net blotch; * $P \leq 0.05$; ** $P \leq 0.01$.

Table 3

PARTITIONING OF SUM OF SQUARES $\left(\eta^{2}\right)$ FOR HULLESS BARLEY AGRONOMIC TRAITS, PRIEKUL,I, STENDE, 2007-2009

\begin{tabular}{|c|c|c|c|c|c|c|c|c|c|}
\hline Source & df & $\mathrm{GY}^{1}$ & DTH & GFP & DTM & LOD & PM & NB & THR \\
\hline Genotype (G) & 60 & $27^{* * 2}$ & $52^{* *}$ & $15^{* *}$ & $25^{* *}$ & $18^{* * *}$ & $32^{* *}$ & $10^{* *}$ & $21^{* * *}$ \\
\hline Year (Y) & 2 & $27^{* *}$ & $8^{* *}$ & $51^{* *}$ & $55^{* *}$ & $8^{* *}$ & $4^{* *}$ & $31^{* * *}$ & $1^{* *}$ \\
\hline Location (L) & 1 & $3^{* *}$ & $9^{* *}$ & $1 *$ & $1^{* *}$ & $32^{* * *}$ & $45^{* *}$ & $3^{* *}$ & $2^{* *}$ \\
\hline Gx $\mathrm{Y}$ & 120 & $9^{* *}$ & $3^{* *}$ & $3^{* * *}$ & $3^{* *}$ & $6^{* *}$ & $4^{* *}$ & $23^{* *}$ & $14^{* *}$ \\
\hline Y X L & 2 & $1^{* *}$ & $21^{* *}$ & $25^{* *}$ & $10^{* *}$ & $13^{* *}$ & $1^{* *}$ & $7^{* *}$ & $1^{* * *}$ \\
\hline Gx L & 60 & $6^{* * *}$ & $2^{* *}$ & $2^{* * *}$ & $1^{* *}$ & $8^{* *}$ & $4^{* *}$ & $5^{* *}$ & $6^{* *}$ \\
\hline Gx Y x L & 120 & $5^{* *}$ & $4^{* *}$ & $4^{* *}$ & $4^{* *}$ & $6^{* *}$ & $3^{* *}$ & $6^{* *}$ & $15^{* *}$ \\
\hline
\end{tabular}

Priekuḷi and Stende, respectively. Significantly higher values of this trait in both growing locations were observed for hulless barley, but a greater difference between minimum and maximum values of these traits was found for hulled barley (Table 4). There was a significant difference between years of investigation and the longest period from sowing to heading was in 2009 for both types of barley (Table 5).

Grain filling period. The variation in grain filling period was significantly $(P<0.01)$ influenced by all three main factors and their interaction. The partitioning of variance explained was similar for both types of barley. The main effect of variation was due to year, genotype and year * location interaction $\left(\eta_{\text {hulled }}^{2}=25-36 \%, \eta_{\text {hulless }}^{2}=15-51 \%\right)$. The variation in grain filling period explained was higher for hulled barley in both locations and in all years of investigation and there was a significant difference between mean values of hulled and hulless genotypes (Tables 4, 5). For both types of barley the highest average values of this trait were in the Stende location and in year 2008.

Days to maturity. The variation in the duration of vegetation period was affected by all factors and their interaction in both types of barley. The variation in days to maturity was mainly determined by the year $\left(\eta^{2}\right.$ hulled $=42 \%, \eta_{\text {hulless }}^{2}$ $=55 \%)$ and genotype $\left(\eta_{\text {hulled }}^{2}=29 \%, \eta_{\text {hulless }}^{2}=25 \%\right)$ and to a lesser extent by location. Variation in length of period of vegetation in both types of barley was also due to $\mathrm{Y}^{*} \mathrm{~L}$ interaction $\left(\eta_{\text {hulled }}^{2}=10 \%, \eta_{\text {hulless }}^{2}=15 \%\right)$. A significant difference between mean values for days to maturity was observed among locations; in Priekuli this period was longer for both types of barley. Higher variation explained was

$$
\text { Table } 4
$$

ESTIMATES OF GRAND MEAN AND RANGE FOR AGRONOMIC TRAITS IN BARLEY IN TWO LOCATIONS (2007-2009)

\begin{tabular}{|c|c|c|c|c|c|c|c|}
\hline \multirow[t]{2}{*}{ Trait } & \multirow{2}{*}{$\begin{array}{l}\text { Loca- } \\
\text { tion }^{1}\end{array}$} & \multicolumn{3}{|c|}{ Hulled } & \multicolumn{3}{|c|}{ Hulless } \\
\hline & & mean $^{2}$ & $\min -\max$ & range & mean & min-max & range \\
\hline \multirow{2}{*}{$\begin{array}{l}\text { Grain yield, } \\
\text { t ha }^{-1}\end{array}$} & $\mathrm{P}$ & $4.4 b^{*}$ & $1.6-5.9$ & 4.3 & $3.2 \mathrm{~b}$ & $1.5-4.2$ & 2.7 \\
\hline & S & $4.6 a^{*}$ & $1.8-6.2$ & 4.4 & $3.6 \mathrm{a}$ & $2.1-5.1$ & 3.0 \\
\hline \multirow{2}{*}{$\begin{array}{l}\text { Days to head- } \\
\text { ing }\end{array}$} & $\mathrm{P}$ & $57 \mathrm{a}$ & $43-63$ & 20 & $58 \mathrm{a}^{*}$ & $51-61$ & 10 \\
\hline & S & $55 \mathrm{~b}$ & $44-61$ & 17 & $56 b^{*}$ & $53-62$ & 9 \\
\hline \multirow{2}{*}{$\begin{array}{l}\text { Filling } \\
\text { period }\end{array}$} & $\mathrm{P}$ & $45 \mathrm{a}^{*}$ & $41-56$ & 15 & $44 a$ & $41-49$ & 8 \\
\hline & S & $46 b^{*}$ & $42-66$ & 24 & $45 b$ & $42-50$ & 8 \\
\hline \multirow{2}{*}{$\begin{array}{l}\text { Days to } \\
\text { maturity }\end{array}$} & $\mathrm{P}$ & $102 \mathrm{a}$ & $96-108$ & 12 & $102 \mathrm{a}$ & 99-107 & 8 \\
\hline & S & $101 \mathrm{~b}$ & $94-111$ & 17 & $101 \mathrm{~b}$ & 97-106 & 9 \\
\hline \multirow{2}{*}{$\begin{array}{l}\text { Lodging, } \\
\text { scores }\end{array}$} & $\mathrm{P}$ & $8.6 \mathrm{a}$ & $5.4-9.0$ & 3.6 & $8.8 \mathrm{a}$ & $6.3-9.0$ & 2.7 \\
\hline & S & $6.8 \mathrm{~b}$ & $4.1-8.6$ & 4.5 & $6.8 \mathrm{~b}$ & $3.8-8.8$ & 5.0 \\
\hline \multirow{2}{*}{$\begin{array}{l}\text { Treshability, } \\
\text { scores }\end{array}$} & $\mathrm{P}$ & - & - & - & $0.8 \mathrm{~b}$ & $0.0-3.4$ & 3.4 \\
\hline & $S$ & - & - & - & $1.0 \mathrm{a}$ & $0.1-1.9$ & 1.8 \\
\hline \multirow{2}{*}{$\begin{array}{l}\text { Powdery mil- } \\
\text { dew, scores }\end{array}$} & $\mathrm{P}$ & $0.8 \mathrm{~b}$ & $0.0-3.2$ & 3.2 & $1.1 b^{*}$ & $0.0-3.2$ & 3.2 \\
\hline & S & $2.3 \mathrm{a}$ & $0.0-3.4$ & 3.3 & $2.6 a^{*}$ & $0.1-3.5$ & 3.4 \\
\hline \multirow{2}{*}{$\begin{array}{l}\text { Net blotch, } \\
\text { scores }\end{array}$} & $\mathrm{P}$ & $0.8 b^{*}$ & $0.1-1.9$ & 1.8 & $0.5 b$ & $0.0-1.2$ & 1.2 \\
\hline & S & $0.9 a^{*}$ & $0.1-1.7$ & 1.6 & $0.7 \mathrm{a}$ & $0.2-1.6$ & 1.4 \\
\hline
\end{tabular}

${ }^{1}$ P, Priekulii; S, Stende; ${ }^{2}$ trait means followed by different letters are significantly different between the locations at the level of $P<0.05$; * indicates trait means that are significantly higher for hulled or hulless barley at the level of $P<0.05$. 
Table 5

ESTIMATES OF GRAND MEAN AND RANGE FOR AGRONOMIC TRAITS IN BARLEY IN THREE YEARS (2007-2009)

\begin{tabular}{|c|c|c|c|c|c|c|c|}
\hline \multirow[t]{2}{*}{ Trait } & \multirow[t]{2}{*}{ Year } & \multicolumn{3}{|c|}{ Hulled } & \multicolumn{3}{|c|}{ Hulless } \\
\hline & & mean $^{1}$ & $\min -\max$ & range & mean & $\min -\max$ & range \\
\hline \multirow{3}{*}{$\begin{array}{l}\text { Grain yield, } \\
\mathrm{t} \mathrm{ha}^{-1}\end{array}$} & 2007 & $3.5 \mathrm{c}$ & $0.7-5.7$ & 5.0 & $2.7 \mathrm{c}$ & $1.1-4.0$ & 2.9 \\
\hline & 2008 & $4.5 b$ & $2.0-6.0$ & 4.0 & $3.6 b$ & $2.1-4.6$ & 2.5 \\
\hline & 2009 & $5.4 \mathrm{a}$ & $1.8-7.2$ & 5.4 & $3.9 \mathrm{a}$ & $2.0-5.3$ & 3.3 \\
\hline \multirow{3}{*}{$\begin{array}{l}\text { Days to } \\
\text { heading }\end{array}$} & 2007 & $55 \mathrm{c}$ & $45-62$ & 17 & $56 c$ & $51-62$ & 11 \\
\hline & 2008 & $56 b$ & $42-62$ & 20 & $57 b$ & $52-62$ & 10 \\
\hline & 2009 & $57 \mathrm{a}$ & $44-63$ & 19 & $58 \mathrm{a}$ & $54-62$ & 8 \\
\hline \multirow{3}{*}{$\begin{array}{l}\text { Filling } \\
\text { period }\end{array}$} & 2007 & $43 c$ & $38-56$ & 18 & $42 c$ & $38-49$ & 11 \\
\hline & 2008 & $49 a$ & $45-59$ & 14 & $49 a$ & $45-53$ & 8 \\
\hline & 2009 & $44 b$ & $40-55$ & 15 & $44 b$ & $40-48$ & 8 \\
\hline \multirow{3}{*}{$\begin{array}{l}\text { Days to } \\
\text { maturity }\end{array}$} & 2007 & $99 \mathrm{c}$ & $92-103$ & 11 & $98 \mathrm{c}$ & $94-102$ & 8 \\
\hline & 2008 & $105 \mathrm{a}$ & 98-111 & 13 & $105 \mathrm{a}$ & $103-111$ & 8 \\
\hline & 2009 & $101 b$ & $94-112$ & 18 & $101 \mathrm{~b}$ & $97-106$ & 9 \\
\hline \multirow{3}{*}{$\begin{array}{l}\text { Lodging, } \\
\text { scores }\end{array}$} & 2007 & $8.5 \mathrm{a}$ & $5.5-9.0$ & 3.5 & $8.5 \mathrm{a}$ & $6.0-9.0$ & 3.0 \\
\hline & 2008 & $7.2 \mathrm{~b}$ & $4.5-8.7$ & 4.2 & $7.4 \mathrm{~b}$ & $4.8-8.7$ & 3.9 \\
\hline & 2009 & $7.3 b$ & $2.1-9.0$ & 6.9 & $7.4 \mathrm{~b}$ & $4.2-9.0$ & 4.8 \\
\hline \multirow{3}{*}{$\begin{array}{l}\text { Treshability, } \\
\text { scores }\end{array}$} & 2007 & - & - & - & $0.97 \mathrm{a}$ & $0.2-2.0$ & 1.8 \\
\hline & 2008 & - & - & - & $0.82 b$ & $0.0-2.1$ & 2.1 \\
\hline & 2009 & - & - & - & $0.81 b$ & $0.0-4.7$ & 4.7 \\
\hline \multirow{3}{*}{$\begin{array}{l}\text { Powdery } \\
\text { mildew, } \\
\text { scores }\end{array}$} & 2007 & $1.5 \mathrm{~b}$ & $0.0-3.9$ & 3.8 & $1.8 \mathrm{~b}$ & $0.2-3.4$ & 3.2 \\
\hline & 2008 & $1.3 \mathrm{c}$ & $0.0-3.3$ & 3.3 & $1.6 \mathrm{c}$ & $0.0-3.3$ & 3.3 \\
\hline & 2009 & $1.8 \mathrm{a}$ & $0.0-3.3$ & 3.3 & $2.1 \mathrm{a}$ & $0.0-3.4$ & 3.4 \\
\hline \multirow{3}{*}{$\begin{array}{l}\text { Net blotch, } \\
\text { scores }\end{array}$} & 2007 & $1.0 \mathrm{~b}$ & $0.1-2.1$ & 2.0 & $0.6 b$ & $0.0-1.7$ & 1.7 \\
\hline & 2008 & $1.3 \mathrm{a}$ & $0.2-2.2$ & 2.0 & $1.1 \mathrm{a}$ & $0.3-1.9$ & 1.6 \\
\hline & 2009 & $0.2 \mathrm{c}$ & $0.0-1.3$ & 1.3 & $0.1 \mathrm{c}$ & $0.0-0.7$ & 0.7 \\
\hline
\end{tabular}

${ }^{1}$ trait means followed by different letters within a row are significantly different between the years at the level of $P<0.05$

observed for hulled barley genotypes. The difference between earliest and latest genotype was 12 days in Priekuli and 17 days in Stende (Table 4). Mean number of days to maturity was significantly higher in 2008 (Table 5).

Lodging resistance. The variation in lodging resistance for both types of barley was significantly $(P<0.01)$ influenced by all investigated factors. The main effect on variation in this trait was due to location $\left(\eta^{2}\right.$ hulled $=27 \%, \eta_{\text {hulless }}^{2}=$ $32 \%$ ). For both types of barley the variation of lodging resistance was also determined significantly by genotype and $\mathrm{Y} * \mathrm{~L}$ interaction. The difference between minimum and maximum values was higher and mean lodging resistance was significantly $(P<0.05)$ lower in Stende than in the Priekuli location (Table 3). Significantly higher resistance to lodging was observed in 2007 for both types of barley, compared to that in 2008 and 2009 (Table 5).

Threshability. For hulless barley, the variation of threshability among years and locations was significantly $(P<$ $0.01)$ influenced by all factors investigated. Genotype, $\mathrm{G} *$ $\mathrm{Y}$ and $\mathrm{G} * \mathrm{Y} X \mathrm{~L}$ interactions explained the major part of the variation of this trait (Table 3 ). Higher variation explained for hulless genotypes (score 0.0-3.4) and better threshability was observed in the Priekul, location (Table 4). There were significant differences in the variation of threshability among the years, and a better mean result (lower trait value) was obtained in 2008 and 2009.

Infection with powdery mildew. The variation in this trait for hulled and hulless barley in the tested varieties was highly significantly $(P<0.01)$ influenced by all three factors and their interaction (Tables 2, 3). For both types of barley the variation of yield was mainly determined by genotype $\left(\eta_{\text {hulled }}^{2}=34 \%, \eta_{\text {hulless }}^{2}=32 \%\right)$ and location $\left(\eta_{\text {hulled }}^{2}=41 \%, \eta_{\text {hulless }}^{2}=45 \%\right)$ and to a lesser extent by year and interaction of factors. The mean resistance to powdery mildew in hulled barley genotypes was higher (lower trait values obtained) in the Priekuli location (score 0.8) than in Stende growing conditions (score 2.3). The same result was observed also for hulless barley (1.1 and 2.6 scores, respectively) (Table 4). There was a significant difference in mean scores of powdery mildew between different years of investigation. The highest infection of powdery mildew for both types of barley was found in 2009 (Table 5).

Infection with net blotch. Year, genotype and $G^{*} \mathrm{Y}$ interaction were the main factors explaining $(P<0.01)$ variation of infection level with net blotch for both types of barley. The sum percentage of variance explained by these factors was $60 \%$ for hulled genotypes and $64 \%$ for hulless genotypes (Tables 2, 3). The mean level of infection with net blotch of hulled barley genotypes was significantly lower in the Priekuli location (score 0.8) than in Stende (score 0.9). The same was observed also for hulless barley (score 0.5 and 0.7 , respectively) (Table 4). There was a significant difference in mean score of net blotch between years. The highest infection of net blotch for both types of barley was found in 2008 (mean score of 1.3 and 1.1 for hulled and hulless barley, respectively) (Table 5).

Broad-sense heritability estimated on the basis of genotypical and phenotypical variances for all traits of hulled barley varied from 31 to 98 , and for hulless barley from 42 to $98 \%$ (Fig. 1). For both types of barley the lowest heritability values were determined for grain yield, lodging and infection with net blotch powdery mildew. For both types of barley

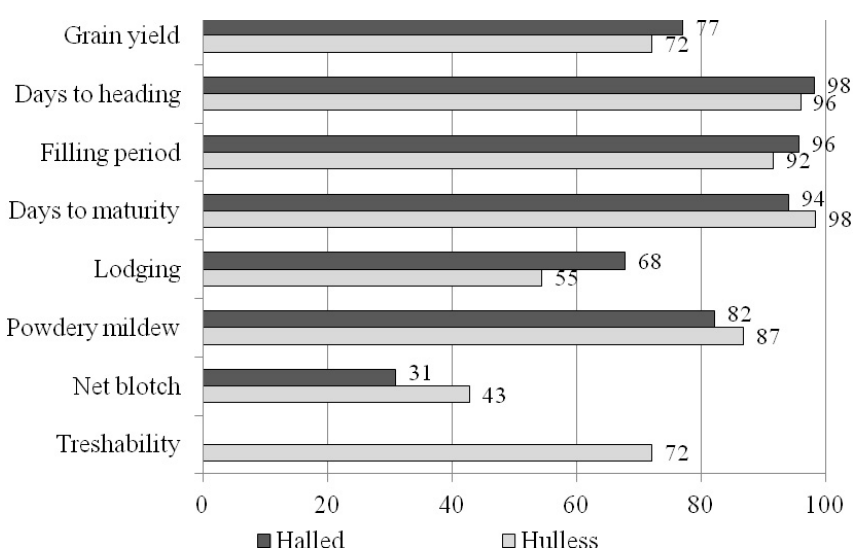

Fig. 1. Broad-sense heritability $\left(\mathrm{H}^{2}, \%\right)$ of evaluated hulled and hulless barley traits, Priekuli, Stende, 2007-2009. 
the highest heritability were observed for days to heading, filling period and days to maturity.

\section{DISCUSSION}

Agronomic traits of barley are of great importance for a breeder in order to match the demand of farmers. Genetic variability present in working collections of breeders is an important resource for generation of new variety ideotypes with desired traits for increased crop production and quality. Genetic variation of yield and other agronomic traits of spring barley over several years and locations has been intensively studied (Esparza Martinez and Foster, 1998; Nurminiemi et al., 2002; Ingver et al., 2010; KolodinskaBrantestam et al., 2010; Przulj and Momcilovic, 2010). Our study showed high significant variation among the spring barley genotypes for all investigated agronomic traits. Days to heading and resistance to powdery mildew showed the highest partitioning of sum of squares for genotype in both types of barley.

In all of the studied traits the extensive variability among accessions was attributed not only by genetic differences but also by the environment. Variance explained by year of investigation was significant for all traits and for phenological traits - grain filling period and length of vegetation period explained most of the variance in both hulled and hulless barley (Tables 2, 3). The trait days from sowing to heading were to a large extent affected by interaction of year and location. The high influence of year on phenological traits can be attributed to changing temperature during the vegetation period. The 2007 season was rather unfavourable for spring barley growing for both types of barley due to high air temperature higher than long term average in Priekuli and Stende (in May by $1.4{ }^{\circ} \mathrm{C}$ and $1.6{ }^{\circ} \mathrm{C}$ and in June $2.1{ }^{\circ} \mathrm{C}$ and $2.2{ }^{\circ} \mathrm{C}$, respectively) and water deficit during the growing season, which decreased productivity of spring barley. Elevated temperature is known to decrease the length of the vegetation period. Similar results were found also by Przulj and Momcilovic (2010); in that study the length of period to heading was mainly influenced by genotype and year, and to a lesser extent by interaction of factors. Yield is closely related to total crop canopy photosynthesis and a decrease of the length of vegetation period can result in decrease of total photosynthesis and thus yield (Araus et al., 2008). Differences in environmental conditions between years also was the major factor influencing net blotch infection. Significant differences between years were found for all agronomic traits, except for lodging resistance and threshability in 2008 and 2009.

The expected increased precipitation due to climate changes most likely would have a negative effect on disease spread and lodging. Net blotch and powdery mildew of barley is a widespread disease in Latvia. Our results also suggested that the diseases are competing for the green area of leaves. The maritime conditions at the Stende location are usually favourable for evaluation of spring barley breeding material to powdery mildew and net blotch resistance. Also in this study, a significantly higher infection level of both of these leaf diseases was observed at Stende location, which can be explained by higher average precipitation in all three seasons of vegetation compared to Priekuli. In Stende in all three years the monthly average precipitation exceeded the long-term average, except in 2007 June and deviations from the long-term average of the growing seasons were 11.8, 65.6, 61.1 $\mathrm{mm}$ in consecutive years form 2007 to 2009. In Priekuli, the deviation from the long-term average was smaller: $12.2,3.02$ and $0.32 \mathrm{~mm}$ in 2007 to 2009, respectively and months with positive and negative deviations from long-term average were observed in each year. In 2009, which was characterised by wet June and July months, significantly higher infection with powdery mildew was observed for both types of barley, compared with other years, but net blotch infection level was the lowest. There was rather high variation in resistance to powdery mildew within both types of barley. Eleven genotypes were not infected by this disease during the three years. Comparatively high effect of location was found also for lodging. The meteorological and growing conditions in Stende caused lodging to a higher extent than in Priekuli, which can be explained by thunderstorms with heavy wind and by a greater precipitation in Stende in 2008 and 2009.

High values for the $\mathrm{G} * \mathrm{Y}, \mathrm{G} * \mathrm{~L}$, and $\mathrm{Y} * \mathrm{X} * \mathrm{~L}$ interaction indicated different ranking of the varieties in years and locations. In this study the $\mathrm{G} * \mathrm{Y}$ variance component was significant for all traits and for both types of barley. The highest influence on variation due to this factor was for infection with net blotch and threshability. Understanding of environmental and genotypic causes of $\mathrm{G} * \mathrm{Y}$ and $\mathrm{G} * \mathrm{~L}$ interactions is important at all stages of plant breeding, including ideotype design, parent selection based on traits, and selection based on desirable traits (Jackson et al., 1996). In general, heritability was low for characteristics with agronomical importance, such as yield, since these characteristics are influenced by a large number of genes. Our study showed that the highest heritability was for phenological traits. The lower values of broad-sense heritability estimated for infection level with diseases and threshability indicated greater interaction year and location.

Several authors have studied broad-sense heritability for yield and other agronomic traits of spring barley over several years and locations. High values of broad-sense heritability for phenological traits were obtained also in the study of Przulj and Momcilovic (2010). In the study of Comadran et al. (2008), the broad sense heritability for yield ranged from $2 \%$ to over $80 \%$. Regarding $\mathrm{G} * \mathrm{E}$ interaction and heritability estimates of net blotch resistance, the broad sense heritability values were large using data from a specific environment and low using estimates from different growing conditions. In a specific environment, resistance related parameters were found to be genetically associated (Cherif, 2010). If heritability was estimated for a single season and single location in our study, the heritability estimate might be higher. 
This research showed that the effects of environment, genotype * year interaction and genotype * location interaction contributed to observed differences between varieties. Evaluation of genotypes in multiple environments with replicated design allows better estimation of breeding values of genotypes, but it requires additional time and expense. The phenotyping data of this study showed availability of significant genetic variability for both types of barley, which indicated that selection of parent genotypes and future genetic studies may be conducted with respect to these traits.

Ninety five of the genotypes of this study were genotyped with Illumina high-throughput genotyping with 1536 SNP markers (Close et al., 2009) to carry out genome wide association mapping with the potential to find significant marker-trait associations that could be used to design molecular markers for marker assisted selection. The relatively high estimated heritability is indicative of large genetic control over trait and suggests that association mapping could be successful.

\section{ACKNOWLEDGEMENTS}

This research was performed with financial support of the Latvian State Research Programme in Agrobiotechnology and European Social Fund co-financed Project 2009/0218/ 1DP/1.1.1.2.0/09/APIA/VIAA/099.

\section{REFERENCES}

Araus, J.L., Slafer, G.A., Royo, C., Serret, M.D. (2008). Breeding for yield potential and stress adaptation in cereals. Crit. Rev. Plant Sci., 27, $377-412$.

Basford, K.E., Cooper, M. (1998). Genotype X environment interaction and some considerations of their implication for wheat breeding in Australia. Austral. J. Agr. Res., 4, 153-174.

Cherif, M., Rezgui, S., Devaux, P., Harrabi, M. (2010). Genotypexenvironment interactions and heritability of quantitative resistance to net blotch in Tunisian barley. J. Plant Breed. Crop Sci., 2(5), 110-116.

Close, T., Bhat, P., Lonardi, S., Wu, Y., Rostoks, N., Ramsay, L., Druka, A., Stein, N., Svensson, J., Wanamaker, S., Bozdag, S., Roose, M., Moscou, M., Chao, S., Varshney, R., Szucs, P., Sato, K., Hayes, P., Matthews, D., Kleinhofs, A., Muehlbauer, G., DeYoung, J., Marshall, D., Madishetty, K., Fenton, R., Condamine, P., Graner, A., Waugh, R. (2009). Development and implementation of high-throughput SNP genotyping in barley. BMC Genomics, 10, 582.

Comadran, J., Russell, J. R., van Eeuwijk, F. A., Ceccarelli, S., Grando, S., Baum, M., Stanca, A. M., Pecchioni, N., Mastrangelo, A. M., Akar, T. (2008). Mapping adaptation of barley to droughted environments. Euphytica, 161 (1-2), 35-45.

Esparza Martinez, J.H., Foster, A.E. (1998). Genetic analysis of heading date and other agronomic characters in barley (Hordeum vulgare L.). Euphytica, 99(3), 145-153.

Dai, A. (2011). Drought under global warming. WIREs Climate Change, 2, 45-65.

Gauch, H.G., Zobel, R.W. (1997). Identifying mega-environments and targeting genotypes. Crop Sci., 37, 311-326.

Gordon, I.L., Byth, D.E., Balaam, L.N. (1972). Variance of heritability ratios estimated from phenotypic variance components. Biometrics, 28, 401-405.

Ingver, A., Tamm, I., Tamm, Ü., Kangor, T., Koppel, R. (2010). The characteristics of spring cereals in changing weather in Estonia. Agron. Res., 8, $553-562$.

Jackson, P., Robertson, M., Cooper, M., Hammer, G. L. (1996). The role of physiological understanding in plant breeding: From a breeding perspective. Field Crops Res., 49, 11-37.

Kolodinska-Brantestam, A., von Bothmer, R., Rashal, I., Gullord, M., Martynov, S., Weibull, J. (2010). Variation of agronomic traits in Nordic and Baltic spring barley. In: Proceedings of the 10th International Barley Genetics Symposium, 5-10 April, 2008, Alexandria (pp. 39-45). Cecarelly, S., Grando, S. (eds.). Alexandria.

Legzdina, L., Mezaka, I. (2010). Progress of the hulless barley breeding program. In: Proceedings of the 10th International Barley Genetics Symposium. 5-10 April, 2008, Alexandria (pp. 61-67). Cecarelly, S., Grando, S. (eds.). Alexandria.

Novoselovic, D., Baric, M., Drezner, G., Gunjaca, J., Lalic, A. (2004). Quantitative inheritance of some wheat plant traits. Genet. Mol. Biol, 27(1), 92-98.

Nurminiemi, M., Madsen, S., Rognli, O., Bjornstad, A., Ortiz, R. (2002). Analysis of the genotype-by-environment interaction of spring barley tested in the Nordic Region of Europe: Relationships among stability statistics for grain yield. Euphytica, 127, 123-132.

Olesen J.E., Trnka M., Kersebaum K.C., Skjelvag, A.O., Seguin, B, Peltonen-Saino, P., Rossi, F., Kozyra, J., Micale, F. (2011). Risk assessment and foreseen impacts on agriculture. Eur. J. Agron., 43, 96-112.

Przulj, N., Momcilovic, V. (2010). Characteristics of malting barley in southern Europe I. Spring barley. In: Proceedings of the 10th International Barley Genetics Symposium, 5-10 April, 2008, Alexandria (pp. 484-494). Cecarelly, S., Grando, S. (eds.). Alexandria.

Rossnagel, B.G. (2000). Hulless barley - Western Canadas corn. In: Proceedings of the 8th International Barley Genetics Symposium, 22 Proceedings of the 8th International Barley Genetic Symposium, 27 October 2000, Adelaide (pp. 135-142). Logue, S. (Ed.). Glen Osmond: Adelaide University.

Received 15 March 2012

\section{NOZĪMĪGU AGRONOMISKO PAZĪMJU MAINĪBA KLIMATA PĀRMAIṆU KONTEKSTĀ LATVIJAS VASARAS MIEŽU SELEKCIJAS PROGRAMMĀS}

Globālās klimata pārmaiņas ir jauns izaicinājums arī Latvijas vasaras miežu (Hordeum vulgare L.) selekcijas programmās. Pētījumā izvērtēta graudu ražas, fenoloğisko pazīmju, veldrēšanās, infekcijas pakāpes ar miltrasu un tīklplankumainību, graudu kuḷamības mainība un šo pazīmju iedzimstamība 129 plēkšnainajiem un 61 kailgraudu genotipam no Latvijas miežu selekcijas un kolekcijas materiāla. Lauka izmēǵinājumi iekārtoti Valsts Priekuḷu Laukaugu selekcijas institūtā un Valsts Stendes Graudaugu selekcijas institūtā no 2007. līdz 2009. gadam. Visu izvērtēto faktoru (škirne, gads, vieta) un to mijiedarbības ietekmes īpatsvars uz pazīmju mainību bija būtisks. Pazīmju iedzimstamība variēja no 31 līdz 98\% plēkšnainajiem miežiem, no 42 līdz 98\% kailgraudu miežiem. Gan plēkšnainajiem, gan kailgraudu miežiem augstākā iedzimstamība bija fenoloğiskajām pazīmēm — veǵetācijas perioda garumam, perioda garumam no sējas līdz plaukšanai, un perioda garumam no plaukšanas līdz pilngatavībai. 